\title{
THE JOURNAL OF BIOLOGICAL CHEMISTRY
}

Founded by Christian A. Herter and sustained in part by the Christian A. Herter Memorial Fund

EDITORIAL BOARD

RUDOLPH J. ANDERSON REGINALD M. ARCHIBALD W. MANSFIELD CLARK

HANST. ZLARKE

CARL F. C ORI

EDWARD A. DOISY
JOSEPH S. FRUTON WENDELL H. GRIFFITH A. BAIRD HASTINGS HOWARD B. LEWIS ELMER V. MCCOLLUM WILLIAM C. ROSE WARREN M. SPERRY
WILLIAM C. STADIE EDWARD L. TATUM DONALD D. VAN SLYKE HUBERT B. VICKERY VINCENT DU VIGNEAUD HARLAND G. WO('D

\section{EDITORIAL OFFICE}

Sterling Tower, Yale University, New Haven, Connecticut

Subscription Price: fi. 6s. 6d. per volume, $£^{6}$. 12s. 6d. per year

Subscriptions may be sent to the Periodical Department

BAILLIERE, TINDALL \& COX, 7-8 HENRIETTA ST., LONDON, W.C. 2

FULL PARTICULARS OF THE

\section{JOURNALS}

PUBLISHIZD BY THE

CAMBRIDGE UNIVERSITY PRESS

MAY BE HAD FROM

I'HE MANAGER, CAMBRIDGE UNIVERSITY PRESS

BENTLEY HOUSE, 200 EUSTON ROAD

LONDON, N.W.I 


\title{
FORTHCOMING PAPERS
}

It is hoped to publish the following papers in the next issue of the British Journal of Nutrition:

The Digestion of Pentosans in Hay by Sheep. By R. A. Marshall.

An Outbreak of Nutritional (Iron Deficiency) Anaemia in Weanling Stock Rats. By A.L. BACHARACH, W. F. J. CUTHBertson and DOREEN M. ThORNTON.

Nutrition of Domestic Rabbits. 3. Variations in Carcass Composition of Rabbits Reared for Meat Production. By J. C. D. Hutchinson and C. J. L. BAKER.

Nutrition of Nigerian Peasant Farmers with Special Reference to the Effects of Vitamin A and Riboflavin Deficiency. By B. M. Nicol.

A Photoelectric Spectrophotometer Suitable for the Measurement of Vitamin A by the AntimonyTrichloride Reaction. By S. Y. THOMPSON.

The Conversion of Carotene to Vitamin A in the Intestine. By S. Y. Thompson, J. Ganguly and S. K. KoN.

Conference Proceedings:

Fifty-second Scientific Meeting, 5 March 1949. Nutrition and Fertility.

Abstracts of Communications:

Fifty-first Scientific Meeting, 26 February 1949.

\section{PROCEEDINGS OF THE NUTRITION SOCIETY}

General editor S. K. KON

\author{
PROCEEDINGS OF THE ENGLISH GROUP \\ Edited by E. M. M. HUME and S. K. KON
}

PROCEEDINGS OF THE SCOTTISH GROUP

Edited by E. W. H. CRUICKSHANK, W. M. DeANS and I. LeITCH

Published for The Nutrition Sociely by W. Heffer \& Sons, Ltd., 3 \& 4 Petty Cury, Cambridge, England

Price: 25 s. net per volume; single numbers 7 s. $6 \mathrm{~d}$. net, double numbers $15 \mathrm{~s}$. net

The Proceedings of The Nutrition Society contain a full record of papers and discussions at the Scientific meetings of the Society held from its formation in 1941 up to the end of 1946 . Volumes $1-5$, containing reports of meetings held during 1941-1946, have been published. In all, reports are available of 37 Scientific Conferences of the Society, covering a wide range of topics in most fields of nutrition. With the completion of Volume 5 , the Proceedings have ceased appearing separately and are merged in the British Journal of Nutrition, published by the Cambridge University Press.

Inquiries for Volumes 1-5 of these Proceedings should be addressed to the publishers

W. HEFFER \& SONS, LTD.

3 \& 4 PETTY CURY, CAMBRIDGE, ENGLAND 